KALMre, Eda: What a Wonderful World of Legends! Articles on rumours and legends. Tartu: ELM Scholarly Press, 20I8, 306 p.

\title{
What a Wonderful World of Legends!
}

Emili SAMPER PRUNERA

Universitat Rovira i Virgili, Tarragona

Un dels trets que defineixen les llegendes contemporànies és la universalitat i el localisme. Aparentment contradictoris, aquests dos elements es conjuguen de manera diversa en aquests relats que se situen en una localitat concreta $i$, al mateix temps, se'n poden trobar versions (molts cops gairebé idèntiques) en indrets allunyats geogràficament entre ells. Per aquest fet, els estudis sobre rumors i llegendes contemporànies d'un territori concret no només resulten interessants per als acadèmics o estudiosos d'aquell indret (o país), sinó que investigadors d'altres llocs també poden trobar similituds amb les seves pròpies versions. Des de Tartu ens arriba aquest volum que recull articles sobre rumors i llegendes que Eda Kalmre, del Department of Folkloristics de l'Estonian Literary Museum, ha

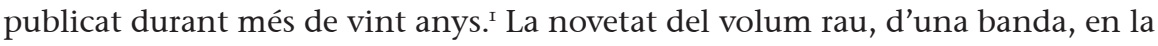
sistematizació dels estudis presentats i, de l'altra, en el fet que el llibre es presenta traduït íntegrament a l'anglès. Aquest darrer fet no és menor, ja que això permet, precisament, que investigadors d'arreu del món puguin conèixer les versions dels rumors i de les llegendes difoses a Estònia en aquest període que l'autora inclou en aquesta selecció de la seva producció acadèmica sobre aquest tema.

En el prefaci, d'un caràcter marcadament personal, ${ }^{2}$ Kalmre fa un repàs històric a l'interès per les llegendes i els rumors a Estònia, partint de les aportacions del folklorista Walter Anderson als anys vint del segle XX. ${ }^{3}$ L'interès inicial de l'autora per aquest gènere del folklore contemporani es deu, sobretot, a la inspiració causada per dos reculls: The Vanishing Hitchhiker, del folklorista nord-americà Jan Harold Brunvand (I933), i Varastettu isoäiti, del folklorista finlandès Leea Virtanen (I935-2002), però també al fet que ella mateixa s'encarregués de gestionar el corpus de llegendes contemporànies dels Estonian Folklore Archives a partir dels anys noranta. ${ }^{4}$ Com ella mateixa explica, "The urban legends collected in the I990s prove that the tradition existed here and was comparable to the stories of similar topic and content in the Western world, although with local differences» (p. II), en una mostra més del caràcter universal i local d'aquest tipus de relats mencionat anteriorment. L'interès de l'autora per les llegendes contemporànies l'ha dut, des del 2004, a participar de manera activa en els congressos europeus de la International Society for Contemporary Legend Research i a ser-ne una de les organitzadores en l'edició que Tallinn va acollir l'any $2016 .{ }^{5}$

I L'article més antic inclòs en el llibre és de 1996 i el més recent de 20I8. En tots els casos s'indica quan i on s'ha publicat cadascun dels articles recopilats en el present volum.

2 L'autora inclou, a més de reflexions sobre la seva trajectòria, fotografies diverses sobre la seva participació en esdeveniments acadèmics.

3 Walter Anderson (I885-I962) va ser professor a la Universitat de Tartu.

4 Kalmre va començar a treballar a l’Estonian Literary Museum l'any I978 (p. I6).

5 La International Society for Contemporary Legend Research (ISLCR) és una associació constituïda l'any I988 dedicada a l'estudi dels rumors i les llegendes contemporànies. Orga- 
No és el primer cop que l'autora publica tota una monografia dedicada al tema. Així, l'any 2013 trobem The Human Sausage Factory. A Study of Post-War Rumour in Tartu, en el qual es fa evident com aquests relats expressen les pors i els temors de la societat que els acull:

These legends and rumours can be interpreted as serious expressions of social anxiety, i.e. they educe fear of strangers and other social groups. While carrying out the research for this book, I realised that this popular multi-layered story is a key that opens the door to the memory bank of personal hope, reeling, fantasy, belief and memory, and through these to an understanding of the society in which these people lived. ${ }^{6}$

Kalmre divideix el llibre en sis seccions diferents, organitzades temàticament.7 En cada secció hi trobem dos articles, excepte en la quarta (formada per un sol article) i en la darrera, que és una miscel-lània formada per tres textos de caràcter més breu.

\section{Guerra i catàstrofe}

La història d'un jove estonià enviat a la guerra d'Afganistan enceta aquesta secció. El rumor se situa a l'any I986 i explica com aquell jove, que feia de cuiner, va salvar la vida gràcies a una serp, que li agraeix haver estat alimentada prèviament per ell. Kalmre reprodueix una versió explicada per Ellen Liiv, cap dels Estonian Folklore Archives, en el transcurs d'un cafè: una nit, la serp s'entortolliga al cos del jove i, sense matar-lo, impedeix que es pugui moure. No és fins al matí que l'allibera i el jove s'adona que, gràcies a l'acció de la serp, ha conservat la vida, ja que la resta dels seus companys han mort aquella nit. L'autora apunta com aquesta història no és l'única que connecta amb la guerra d'Afganistan, que va comptar amb la participació de joves estonians que hi van anar a fer el servei militar (p. 24), però sí que és la més representativa i resulta especialment interessant perquè és un bon exemple de l'adaptació d'aquest tipus d'històries a temps i contextos nous:

As a good folk narratives should, this legend has also survived beyond its temporal limits and offers equal excitement for both the young and the old. And the fact that such a nice and extraordinary story, compared against other urban legends, circulates in the modern world of materialist outlook and technology shows that even today folklore is alive and changing (p. 37).

La catàstrofe del ferri Estonia, ocorreguda la nit del 28 de setembre de 1994 i que va suposar la mort de la major part dels passatgers i de la tripulació en aigües del mar Bàltic, és l'exemple triat per Kalmre per abordar el folklore sobre catàstrofes o «catastrophe-lore». ${ }^{8}$ De manera similar amb el que va succeir amb el conegut accident del Titanic, la catàstrofe del ferri va provocar l'aparició de rumors i

nitza, de manera anual, un congrés (Perspectives on Contemporary Legend) que se celebra, de manera alterna, en territori europeu i nord-americà en col-laboració amb alguna entitat (universitat o centre de recerca) que exerceix d'amfitriona.

6 Eda KAlmRE: The Human Sausage Factory. A Study of Post-War Rumour in Tartu. Amsterdam/ Nova York: Rodopi, 2013, p. I32-I33.

7 Les traduccions de les diferents seccions del llibre són pròpies (i lliures).

8 Kalmre recull aquí la proposta de Maria Hanberger, que utilitza aquesta denominació per a les mostres de folklore sobre catàstrofes, en analogia a denominacions com Xerox-lore (folklore de fotocòpia) o Aids-lore (folklore sobre la sida). 
llegendes de manera simultània, no només a Estònia sinó també en països veïns com Finlàndia i Suècia. El paper de la premsa, en aquest sentit, va ser clau com a element difusor d'aquest tipus de relats: «The majority of legends that spread after the Estonia catastrophe were inspired by and modelled after the materials the media had published about it» (p. 43). L'autora classifica aquestes llegendes en quatre grups diferents: (I) les que expliquen les causes de l'accident; (2) les que sorgeixen al voltant de la misteriosa desaparició del segon capità de l'Estonia; (3) les llegendes sobre persones que van ser abduïdes per ovnis, i, finalment, (4) les històries sobre les víctimes de l'accident que havien trucat a casa quan el vaixell s'enfonsava. Totes elles són un bon exemple de com les persones busquem la sensació de seguretat que ens ofereixen les llegendes en moments crítics, així com de la importància dels mitjans de comunicació com a contribuïdors, disseminadors i amplificadors d'aquests relats.

\section{Una mica d'història}

L'important paper de la premsa amb relació a les llegendes apareix novament en la història dels germans Voitka als anys vuitanta. Ülo i Aivar roben un tractor i s'amaguen al bosc per no ser capturats per la policia. Amb aquesta acció s'evadeixen, també, de fer el servei militar, motiu pel qual són perseguits i buscats per les autoritats militars de la Unió Soviètica. Els dos germans romanen amagats als boscos durant catorze anys i la seva història es converteix en tota una saga, dividida en tres etapes diferenciades: (I) el període en què se'n prioritza la captura; (2) el període que segueix el seu arrest; (3) el període corresponent al judici. De manera similar als relats protagonitzats per altres bandolers, ${ }^{9}$ un dels aspectes fonamentals d'aquesta saga és el tractament dual com a herois i/o criminals dels germans Voitka. No s'escapa a aquest tractament el punt de vista humorístic, exemplificat en aquest cas per part de Kalmre amb la inclusió de diverses il-lustracions humorístiques que recreen, sota la imatge de diferents animals del bosc i amb un to clarament paròdic, els esdeveniments protagonitzats pels dos germans. Una de les mostres d'aquest folklore inspirat pel cas dels germans Voitka és el suposat currículum d'un d'ells (Aivar), que es difon pels webs estonians l'any 2000, acompanyat, però, d'una fotografia de l'altre germà (Ülo). L'autora tanca l'anàlisi de la llegenda amb una cita provinent d'un article d'opinió sobre el cas Voitka com a reflex de l'ànima dels estonians: ${ }^{\text {Io }}$

The story of the Voitka brothers is more about the mentality of the Estonians than about the Voitkas. Looking at the Voitkas we see ourselves, our nature and aspirations. And what we see is not as nice as we wish it to be or as it might be (p. 86).

L'anàlisi de la balada «Saatuse vangis» (Bound by Fate), un exemple de cançó que explica esdeveniments dramàtics sota una forma versificada (esdevinguts, en aquest cas, a Mulgimaa, al sud d'Estònia), serveix a Kalmre per enllaçar aquesta forma més pròpia de les societats d'altres temps (com ara el segle XIX) amb els rumors, les notícies i els entreteniments més recents, en una mostra excel-lent sobre l'evolució del folklore al llarg dels temps i la seva adaptació als canvis que es pro-

9 Com ara el conegut Robin Hood o Jüri Rummo, la seva versió estoniana (p. 68). Io Signat per V. Kolga i publicat a Eesti Päevaleht el 2 de març de 2000 (p. 270). 
dueixen en les societats i en la manera com les persones ens relacionem les unes amb les altres. L'autora ressegueix la versió escrita de la balada (interpretada per Mihkel Rätspe), així com la difusió de la història a la premsa de l'època i inclou, en apèndix, la lletra de la cançó, en versió original i també traduïda a l'anglès.

\section{Els estonians i els altres}

Molts dels rumors i històries que van circular entre els estonians després de la Segona Guerra Mundial estaven relacionats amb judicis de valor i actituds vers els altres, en un context marcat per les circumstàncies socials i polítiques del moment. En aquest sentit, un dels rumors més difosos, no només a Estònia (de manera especial a Tartu) sinó també en altres ciutats europees destruïdes per la guerra, explica l'elaboració de salsitxes a partir de carn humana. En el cas de Tartu, aquesta elaboració es duia a terme en una fàbrica de localització concreta (en unes ruïnes prop del mercat) i està relacionada amb la incertesa del moment i la desaparició de gent:

Tartu's rumour of a sausage factory operating near the market arose as a collective fantasy, and spread in an atmosphere of general fear and uncertainty. The real reasons for that fear were concealed from the community. No one knew how many people disappeared in the post-war years, how much crime there was in the city, how many new residents there were in Tartu and what these people actually did (p. I25-I26).

Aquest rumor reflecteix també l'actitud dels estonians davant dels habitants de països propers amb els quals mantenien, per qüestions polítiques, una relació estreta, com són els alemanys i, sobretot, els russos. Però, alhora, també hi veiem els problemes de divisió de la mateixa societat estoniana, que no són sinó el reflex dels canvis produits amb les mesures adoptades per la Unió Soviètica als anys quaranta, amb la deportació d'estonians cap a Sibèria i altres regions amb el propòsit d'eliminar adversaris potencials. Aquestes mesures van comptar amb la col-laboració d'una part de la societat estoniana (que donava suport al règim soviètic), fet que, de manera inevitable, va provocar una divisió social.

Aquest vessant identitari dels rumors s'aborda també en el segon article d'aquesta secció, dedicat al procés de creació de la identitat estoniana al llarg del temps o, com diu l'autora, grans històries d'una petita nació. Així, aquestes històries especulen sobre la vinculació estoniana de personatges famosos d'àmbits molt diversos, des de Napoleó a Boris Ieltsin, passant per Boris Becker o Lady Di.

\section{Afers sobrenaturals}

Les llegendes de fantasmes (o «ghost-lore») són especialment populars entre els més joves, tot i que no de manera exclusiva. Kalmre dedica aquest capítol a l'estudi de la llegenda de creença sobre «Lilac Lady» que té com a escenari precisament el Literary Museum de Tartu i que ha circulat durant noranta anys. La història, com ja és habitual en aquests casos, és tràgica i explica que aquesta jove es va treure la vida després d'un desencís amorós i, des d'aleshores, no ha trobat mai la pau. L'autora, que ha entrevistat una trentena de persones, vinculades totes elles al museu, ressegueix l'origen de la història i la seva vehiculació, de nou, a través de la premsa de l'època, i estableix cinc etapes diferents en el desenvolupament de la 
llegenda, d'acord amb la proposta d'Ellis: ${ }^{\text {II }}$ (I) l'aparició d'una experiència marginal, encara fora de la tradició i sense estar definida; (2) la verbalització de l'experiència marginal; (3) s'estableix la història que adopta la forma de llegenda; (4) la metonímia: l'audiència reconeix la història, marcada per una paraula que serveix de nucli narratiu i és identificada per l'audiència; (5) el resum de la llegenda (o report): la llegenda és coneguda però ha perdut la seva rellevància i circula en forma de paròdia o de resum breu.

La llegenda de «Lilac Lady» ha perviscut durant molt de temps i apareix de manera recurrent cada cop que es produeix un accident a l'edifici: «Every accident in the house elaborated the legend, revoking the main story for a certain period and prompting the need to talk about it» (p. I82). Resulta molt interessant, en aquest sentit, l'actitud que tenen els receptors de la llegenda, segons la seva creença de la història. Així, trobem creients, escèptics, antagonistes i ambivalents. Cadascun d'ells participa en la formació i la transmissió de la llegenda. ${ }^{12}$ Aquesta transmissió ha canviat al llarg del temps i la llegenda ha esdevingut, d'aquesta manera, una marca de representació del museu, ha aparegut en programes de televisió i ha estat utilitzada com a reclam, fins i tot, pel mateix museu.

\section{Nous mitjans, nous significats}

Kalmre ressegueix en aquesta secció l'evolució de dos grups de llegendes i com la seva forma i transmissió s'ha modificat al llarg del temps. En primer lloc, se centra en el que podríem denominar el maltractament animal, amb unes pràctiques que consisteixen a escorxar gats d'una manera ben peculiar arrencant-los la pell de manera que aquesta surt sencera pel cap de l'animal. Es tracta de la versió, en forma de llegenda contemporània, dels anomenats «tall tales» o exageracions còmiques, que es poden localitzar en tipus rondallístics com l'ATU I896 o el I889B.'³ L'autora ressegueix les versions estonianes d'aquests relats i té en compte, també, la seva presència a Les aventures del Baró de Münchhausen de Gottfried August Bürger de i876, en un exemple de fixació escrita d'històries que circulaven de manera oral al voltant d'un personatge.

En segon lloc, l'autora focalitza l'atenció en el que anomena «llegendes i rumors mercantils» que són aquells que estan protagonitzats per grans empreses i corporacions, al voltant de les quals es generen les històries, habitualment no gaire positives. En el cas concret d'Estònia, i des del vessant gastronòmic, aquests rumors pivoten al voltant de les amanides preparades que es poden trobar habitualment als supermercats, així com en el consum de les pastanagues petites («baby carrots»), l'origen de les quals és sospitós. Tots dos rumors exemplifiquen el conflicte existent entre la societat capitalista i l'excés d'informació:

In other words, these two rumour cycles unveil a conflict between the modern-day capitalist consumer society and the information society.

II Bill ELLIS: «When is Legend? An Essay in Legend Morphology». Dins Gillian BenNETT; Paul SMITH (eds.): The Questing Beast. Perspectives on Contemporary Legend vol. IV (I989): 3I53 .

I2 Kalmre parteix, en aquest cas, de la proposta de Linda DÉGH i Andrew VÁzsonYI: «Legend and Belief». Genre vol. 4 (I97I): 28I-304.

I3 ATU I896 The Man Nails the Tail of the Wolf to the Tree, i ATU I889B Hunter Turns Animal Inside Out, El caçador gira l'animal del revés, en les versions catalanes. 
At the same time, the rumours are not necessarily inspired by a lack of information, which has so far been considered the main reason for the emergence of rumours, but the abundance of information and opinions, a lack of unambiguously understood information (p. 246).

\section{Algunes observacions sobre les llegendes urbanes}

La darrera secció del llibre aplega tres textos breus centrats en llegendes sobre la sida a Estònia, dues llegendes concretes (sobre càmeres de vídeo que permeten veure-hi a través de la roba i sobre enverinaments de dones mitjançant la beguda) i sobre crims de sang. Aquest darrer text resulta especialment interessant pel context en què va aparèixer, ja que acompanyava el programa de mà que els espectadors de l'obra Sweeney Todd. The Demon Barber of Fleet Street van rebre a l'entrada de l'espectacle. ${ }^{\text {I4 }}$

A la part final el llibre hi consten les notes explicatives de cadascun dels textos, en els quals se'n detalla en primer lloc la publicació original i s'especifica si havien estat publicats anteriorment en anglès. La llista de manuscrits i fonts consultades de l'Estonian Folklore Archives precedeix una llista de referències bibliogràfiques completa i que té en compte, com s'ha fet constar en notes anteriors, estudis de referència sobre la matèria estudiada. Per tot plegat, What a Wondeful World of Legends! resulta una lectura del tot recomanable per a estudiosos (i estudiants) de les llegendes contemporànies i els rumors, ja que a partir de l'estudi que l'autora fa d'exemples ben concrets que fan referència a Estònia s'amplia la mirada tenint en compte altres corpus i, sobretot, s'hi aplica de manera pràctica les teories sobre aquests tipus de relats que han dut a terme les veus més autoritzades de l'estudi del folklore contemporani.

I4 L'obra es va estrenar el 2 de juny de 2018 al Grand Building del Vanemuine Theatre (p. 285). 